\title{
Structural equation modeling of internet of things (IoT) adoption for Indonesian Village-Owned Enterprises (BUMDes)
}

Bustami Usman

Department of Government Studies, Universitas Syiah Kuala, Indonesia bustami. usman@unsyiah.ac.id

Ilham Sentosa

Universiti Kuala Lumpur (UniKL) Business School, Malaysia

ilham@unikl.edu.my

Febri Nurrahmi

Department of Communication Studies, Universitas Syiah Kuala, Indonesia febri. nurrahmi@unsyiah.ac.id

\section{Abstract}

This study seeks to examine the antecedents of Internet of Things (IoT) intention and adoption of Indonesian village-owned enterprises (Badan Usaha Milik Desa, BUMDes) by applying the Technology Acceptance Model (TAM). The respondents comprised 237 managers and staff of BUMDes in Aceh, Indonesia. A questionnaire was designed to examine perceived usefulness of IoT on the product and service empowerment, perceived ease of use of IoT, and perceived credibility on IoT, intention to use the technology, and adoption of IoT to the community empowerment in the village setting. The data were analyzed using 
partial least squares structural equation modeling (PLS-SEM). The generated model of IoT showed three significant direct paths between perceived usefulness, perceived credibility on the IoT, and intention as well as between intention and adoption. The re-specified model of IoT adoption indicated two significant direct paths (perceived usefulness to intention and intention to adoption) and introduced three new paths (direct paths from perceived usefulness, perceived ease of use, and perceived credibility to adoption). The final model also established partial mediating effects of intention between Perceived Usefulness, Perceived Ease of Use, and IoT adoption. This study suggests the relevance of TAM to explain IoT adoption in Indonesian village-owned companies.

Keywords: Public Sector Management, Structural Equation Modeling (SEM), IoT Adoption, Indonesian Village-Owned Enterprises (BUMDes), Technology Acceptance Model.

\section{INTRODUCTION}

Internet of Things (IoT) has become an increasingly important topic in this modern society. According to Rayes and Salam (2019), IoT is defined as "the network of things, with clear element identification, embedded with software intelligence, sensors, and ubiquitous connectivity to the Internet." In other words, IoT includes electronic devices that are able to connect to the Internet and share data with other Internet-enabled devices. With the increasing use of Internet and social media, the need to adopt IoT in business has also been enhanced. IoT is essential in advancing economic growth (Popescu, 2015) by increasing the revenue of the supply chain (Yan, 2017). Considering its importance for the macro-economy, a number of governments around the world started to introduce policies to encourage the adoption of IoT across various organizations in various industries. However, adopting IoT requires enormous investment and digital literacy. Therefore, many businesses have struggled to adopt IoT, especially small and medium enterprises (SMEs) (Zaidi \& Faizal, 2017). IoT is more prevalent in major global cities where many big firms are located, making them significant drivers of urban development (Florida, 2002).

A similar trend is also prevalent in Indonesia. Such a trend is supported by the number of internet users in Indonesia that has increased tremendously in recent years. As of December 2019, Indonesia is positioned as the fourth largest 
Internet user in the world, with 171.26 million internet users (Statista, 2020). This indicated a tremendous potential for IoT markets in Indonesia. However, the survival of IoT in this millennium mostly depends on how information technology (IT) has been used in daily operations. Information communication technology (ICT) is something that must be learned and practiced by IoT's users. A certain level of IoT literacy is needed, especially in the use of the Internet for business enhancement.

This study specifically examines the adoption of IoT by one of SMEs in Indonesia, namely village-owned companies (BUMDes). This business entity is a form of small and medium scale enterprises at the village level (Lubis, Rustam, \& Muda, 2017) and is similar in nature to State-owned companies (BUMN) and local government-owned companies (BUMD) (Zulpahmi, Badaruddin, \& Humaizi, 2020). As regulated in Village Law No. 6/2014, BUMDes is a business entity owned by the government and society at the village level or inter-village cooperation mechanism of formation through village deliberations. It is a village business institution managed by the community and village administration in an effort to strengthen the village economy and is formed based on the needs and potential of the village (Zulpahmi et al., 2020). BUMDes is a pillar of rural economic activity in the village, which functions as a social institution and commercial institution (Srirejeki, 2018). BUMDes plays a significant part in community economic empowerment at the village level.

In the context of Indonesia, the government of Indonesia has launched a smart village program encouraging all stakeholders at the village level, including BUMDes, to integrate digital technologies into all sectors in villages (Nurchim \& Nofikasari, 2018). Such a requirement to adopt IoT is challenging for BUMDes operating in rural areas. The number of people accessing the Internet in rural areas is $50 \%$ lower than in urban areas, followed by the lack of digital skills and literacy among rural internet users compared to those in urban areas (Hadi, 2018). On the other hand, previous research has indicated that the adoption of technology has improved the performance of SMEs (Abd Rahman, Kamarulzaman, \& Sambasivan, 2013), such as BUMDes.

Considering that this business entity is a new economic institution operating in rural areas and still needs a strong foundation for IoT adoption, this area has emerged as a necessary topic to be investigated. However, no attention has been paid to assess the adoption of IoT in BUMdes. Previous works on IoT adoption were conducted in other countries (Ibrahim, 2018; Jaafreh, 2018; Kim, Park, \& Choi, 2017), leaving the determinants of IoT adoption in 
BUMDes understudied. Therefore, this study aims to determine the factors affecting the IoT adoption in BUMDes by adopting the technology acceptance model. It attempts to investigate the empirical relationships between perceived usefulness, ease of use, credibility, and IoT adoption. Additionally, this study also investigates the mediating effect of intention on those relationships. By using the technology acceptance model (TAM), the results of this study are expected to fill a research gap by revisiting the relevance of TAM to explain IoT adoption in BUMDes. The findings are intended to inform BUMDes stakeholders to improve the adoption of IoT in their enterprises.

\section{LITERATURE REVIEW}

\section{Technology acceptance model}

Davis (1989) proposed the conceptual model for technology acceptance, called the technology acceptance model (TAM). TAM was put forward to explain the determinants of user behavior towards information technology (Saade, Nebebe, \& Tan, 2007). TAM suggests that the user's intention to use to adopt technology can be explained by two factors: Perceived Ease of Use and Perceived Usefulness (Maranguni \& Granil, 2015). It suggests that users are driven to adopt a new technology primarily because of its functions and secondarily because of the easiness of benefiting from those functions (Jaafreh, 2018). In this study, Perceived Credibility is added to extend TAM as a variable affecting Intention to Use. This model further suggests that intention is directly related to actual usage behavior (Davis, 1989; Davis, Bagozzi, \& Warshaw, 1989; Maranguni! \& Grani】, 2015). The following discusses the relationship between variables in the proposed model:

a. Perceived Usefulness and Intention to Use IoT

Perceived usefulness is defined as the extent to which a person believes that using a particular system will enhance his or her job performance (Davis, 1989). There has been extensive research in the information systems community providing evidence of the significant effect of perceived usefulness on usage intention (Hamid, Razak, Bakar, \& Abdullah, 2016; Kucukusta, Law, Besbes, \& Legohérel, 2015). Davis (1989) found that Perceived Usefulness has a more substantial influence on Intention to Use than Perceived Ease of Use (Marangunić \& Granić, 2015). Users are often willing to overlook some usage difficulties if the service provides the necessary functions. 


\section{b. Perceived Ease of Use and Intention to Use IoT}

Perceived ease of use is defined as to which a person believes that using a particular system will be effortless (Davis, 1989). Perceived ease of use is hypothesized to be a predictor of intention. Extensive research over the past decade provides evidence concerning the significant effect of perceived ease of use on usage intention, either directly (Hamid et al., 2016; Kucukusta et al., 2015) or indirectly through its impact on perceived usefulness (Abdullah, Ward, \& Ahmed, 2016). To prevent the "under-used" useful system problem, information systems need to be both easy to learn and easy to use. If the system is easy to use, it will be less threatening to the individual (Moon \& Kim, 2001). This implies that perceived ease of use is expected to have a positive influence on users' perception of credibility and intention to use IoT.

c. Perceived Credibility and Intention to Use IoT

Perceived credibility is defined as to which one partner believes that the other partner has the required expertise to perform the job effectively and reliably (Ganesan, 1994). Previous research has found that Perceived Credibility contributed to the Intention to Use a new technology (Goyal, Maity, Thakur, \& Srivastava, 2013; Koksal, 2016). Therefore, Perceive Credibility is considered in this study. Perceived credibility also refers to two critical dimensions, security and privacy. Security is defined as the protection of information or systems from unsanctioned intrusions or outflows, while privacy is the protection of various types of data collected (with or without the knowledge of the users) during users' interactions with the Internet (Hoffman, Novak, \& Peralta, 1999). The usage intention of IoT could be affected by users' perceptions of credibility regarding security and privacy issues. Kim et al. (2017) discovered that security to be one of the significant determinants of customer acceptance of IoT.

d. Intention to Use and IoT Adoption

Intention is an indication of a person's readiness to perform a given behavior, and it is considered to be the immediate antecedent of behaviors (Bagozzi \& Yi, 1988). Adoption or behavior is the manifest, observable response in a given situation with respect to a given target (Azjen, 1980). In this context, previous studies have also found a significant relationship between intention and IoT adoption (Jaafreh, 2018; Karahoca, Karahoca, \& Aksöz, 2018). 
Informasi, Vol. 51. No. 1. (2021), 169-194

\section{The Hypotheses of this study}

Based on TAM theory, the research framework consisted of three exogenous and two endogenous variables. Three exogenous variables were hypothesized to have a direct influence on intention to use information technology. Intention was then hypothesized to have a direct impact on the adoption of internet technology. Intention is also assumed to be a mediator between the three exogenous variables and internet adoption (endogenous). The research hypotheses are as follows.

H1 : Perceived usefulness is significantly and positively related to intention.

H2 : Perceived ease of use is significantly and positively related to intention.

H3 : Perceived credibility is significantly and positively related to intention

H4 : Intention is significantly and positively related to adoption.

H5 : Intention mediates the relationship between perceived usefulness and adoption.

H6 : Intention mediates the relationship between perceived ease of use and adoption.

H7 : Intention mediates the relationship between perceived credibility and adoption.

H8 : Perceived Usefulness, Perceived Ease of Use, Perceived Credibility, Internet Intention, and Internet Adoption have a significant interaction in the structural model.

\section{Previous studies}

To date, studies of IoT adoption in SMEs are scarce, let alone the IoT adoption in BUMDes. This study has indicated three previous studies related to this object of study. First, Kim et al. (2017) investigated the adoption of smart home services by analyzing 269 questionnaire responses. They employed a new model combining VAM (Value-based Adoption Model) and TAM. They found that Perceived Value was more affected by Perceived Benefit than Perceived Sacrifice. They further discovered that Privacy Risk and Innovation Resistance were found to limit Perceived Value, while Perceived Value greatly influenced 
Intention to Use.

Second, Jaafreh (2018) surveyed 72 business leaders and staff working in SMEs in the Kingdom of Saudi Arabia to confirm the robustness of TAM. He also extended TAM by adding National Culture dimensions to study the influencing factors on IoT adoption. His findings confirmed the relevance of the model and discovered that the national culture affected user behavior toward acceptance and rejection of new technology.

Third, Ibrahim (2018) surveyed 400 employees from 43 SMEs in the Malaysian state of Selangor to investigate the effects of the moderating variables (age, gender, and experience) on the use of innovations related to ICT. Using the unified theory of acceptance and use of technology (UTAUT) perspective, he found that the four key predictors (performance expectancy, effort expectancy, social influence, and facilitating conditions) significantly influenced technology adoption. He also found that gender and age acted as moderating variables between the four predictors and technology innovation use.

The aforementioned previous studies are relatively comprehensive in explaining factors that affected ICT-related innovation adoption by SMEs. However, their studies were situated in a context that is entirely different from this study. The previous research was conducted in South Korea (Kim et al., 2017), KSA (Jaafreh, 2018), and Malaysia (Ibrahim, 2018), which is completely different from the context of this study. BUMDes is a form of SMEs operating in rural areas of Indonesia where most people lack digital skills and literacy and do not have access to the Internet. Hence, previous findings could not be exercised in the context of BUMDes in Indonesia.

In addition, the fundamental difference between this study and previous studies is the use of theory. Ibrahim (2018) used the UTAUT perspective, while Jaafreh (2018) using TAM with national cultures, and Kim et al. (2017) used a new model combining VAM and TAM. This study employed TAM with an additional antecedent variable (Perceived Credibility). TAM is more appropriate to this study among other technology adoption models since it has become a key model in understanding users' behavior toward the technology. Previous research has confirmed TAM as a valid model to explain and predict technology acceptance behavior (Abdullah et al., 2016).

\section{METHODS}

The questionnaire was adapted from Wang, Wang, Lin, and Tang 
(2003), consisting of 31 observed items, including perceived usefulness (six items), perceived ease of use (six items), perceived credibility (eight items), internet intention (five items) and internet adoption (eight items). The scaling used in this research is the 7-points Likert scale (1-strongly disagree, 2-disagree, 3-slightly disagree, 4-neutral, 5- slightly agree, 6-agree, and 7-strongly agree). The questionnaire also covered the demographic variables, including gender, race, age, education, and monthly income.

Table 1: Measurement

\begin{tabular}{|c|c|c|}
\hline Variable & Code & Measurements \\
\hline $\begin{array}{l}\text { Perceived } \\
\text { Usefulness } \\
\text { (4 items) }\end{array}$ & $\begin{array}{l}\text { PU2 } \\
\text { PU3 } \\
\text { PU4 } \\
\text { PU5 }\end{array}$ & $\begin{array}{l}\text { Using IoT would improve my job performance } \\
\text { Using IoT would increase my productivity } \\
\text { Using IoT would enhance my effectiveness on } \\
\text { the job } \\
\text { Using IoT would make it easier to do my job }\end{array}$ \\
\hline $\begin{array}{l}\text { Perceived Ease } \\
\text { of Use } \\
\text { (5 items) }\end{array}$ & $\begin{array}{l}\text { EOU2 } \\
\text { EOU3 } \\
\text { EOU4 } \\
\text { EOU5 } \\
\text { EOU6 }\end{array}$ & $\begin{array}{l}\text { I would find it easy to use IoT to obtain } \\
\text { decision-making information } \\
\text { My interaction with IoT was clear and } \\
\text { understandable } \\
\text { I found the IoT to be flexible to interact with } \\
\text { It would be easy for me to become skilful at } \\
\text { using IoT. } \\
\text { I found the IoT easy to use }\end{array}$ \\
\hline $\begin{array}{l}\text { Perceived } \\
\text { Credibility } \\
(5 \text { items })\end{array}$ & $\begin{array}{l}\text { CRE1 } \\
\text { CRE2 } \\
\text { CRE3 } \\
\text { CRE4 } \\
\text { CRE6 }\end{array}$ & $\begin{array}{l}\text { IoT has privacy } \\
\text { I feel confident in my activities with IoT. } \\
\text { When using IoT, I am sure that certain } \\
\text { managerial and technical procedures exist to } \\
\text { secure all the data on this system } \\
\text { IoT has a good security system } \\
\text { When using IoT, I am sure of the consistency of } \\
\text { information processing on this system. }\end{array}$ \\
\hline
\end{tabular}




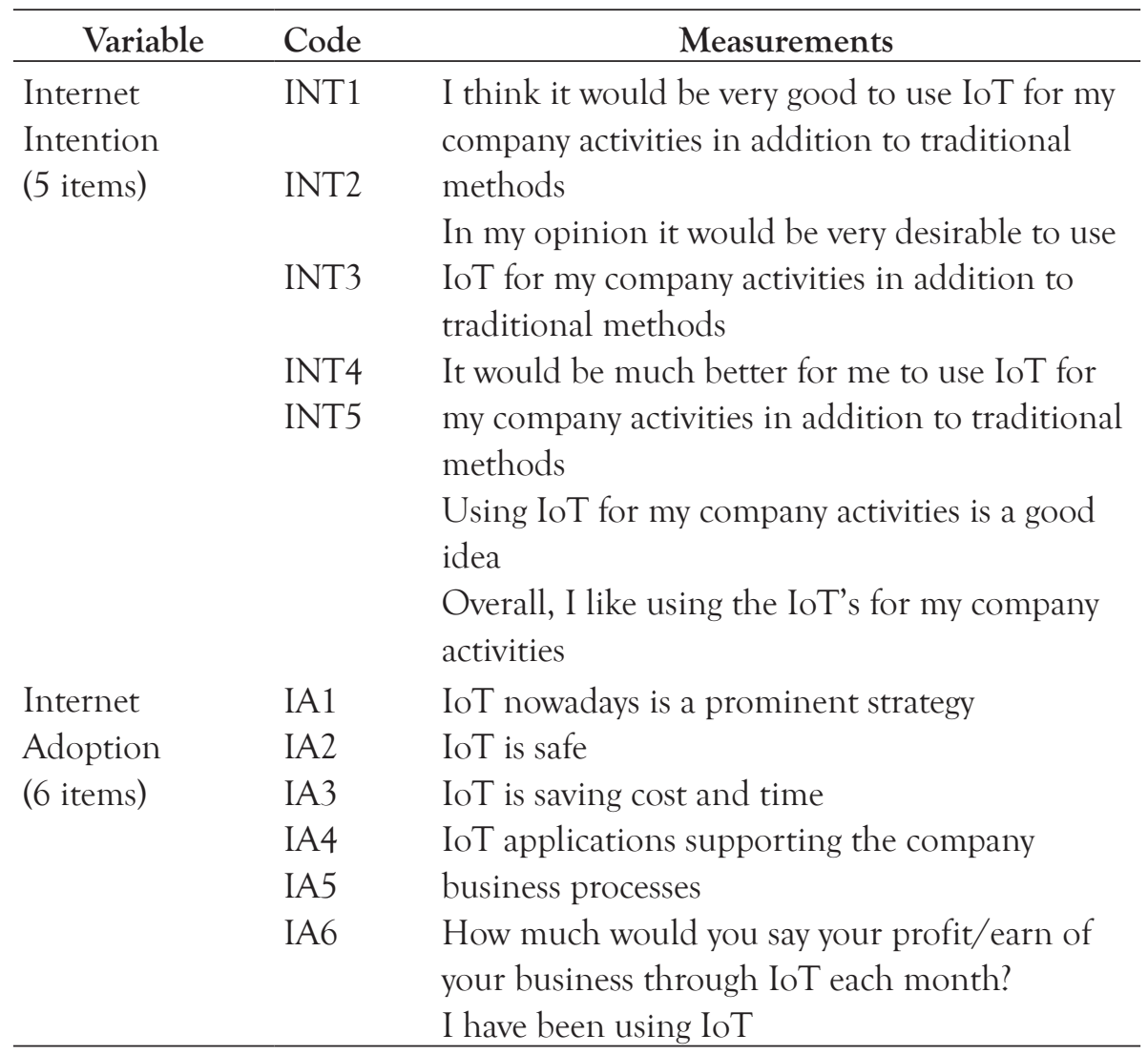

The respondents were Young Creative Entrepreneurs (YCE) working at BUMDes who operated their businesses in Aceh province. A questionnaire containing the measures of the constructs was administered to 305 owners of various products. The questionnaires were distributed to the respondents using the proportionate stratified random sampling method. Out of the desired sample size of 305,245 were returned, indicating a response rate of $80.32 \%$. As such, the response rate for this study is adequate for structural equation modeling (SEM) analysis.

Rigorous data screening procedures were conducted on the raw SPSS data, such as outliers detection as well as reliability, normality, and validity tests. The 245 datasets were coded and saved into IBM SPSS version 25 and analyzed using IBM SPSS AMOS version 25. In this study, a test for multivariate outliers was conducted using the techniques described by Tabachnick, Fidell, and Ullman (2012). The Mahalanobis distance was calculated based on the 31 
observed items. The criterion of $\mathrm{p}<0.001$ and critical value of $\square 2=59.70$ were used. The tests conducted identified eight cases with Mahalanobis values (D2) above 59.70. It implies that the Mahalanobis analysis succeeded in identifying the multivariate outliers, which later were deleted permanently, leaving 237 datasets for further analysis. Several statistical validity tests and analyses were then conducted, including reliability and composite reliability tests, validity tests using confirmatory factor analysis (CFA) for construct validity, discriminant validity for multicollinearity treatment, descriptive analysis, correlation, and structural equation modeling analysis. The steps in SEM analysis were CFA analysis, measurement model analysis of exogenous and endogenous constructs, discriminant analysis, composite reliability analysis and direct/ indirect impact analysis (mediating effect), and finally testing the goodness of fit for the hypothesized and generated model (Al-Jader \& Sentosa, 2015; Rengiah \& Sentosa, 2015).

\section{RESULTS AND DISCUSSION}

The profile of the companies involved in this study indicates that the BUMDes utilized the Internet predominantly for financial services, such as paying bills, salaries, and invoicing (35\%), making order information (24.1\%), electronic e-mail (23.6\%), marketing (23.6\%), submitting tenders to customers (23.6), document transferring (19\%), purchasing raw materials (8.4\%), interaction with the government $(5.1 \%)$, voice or audio communication $(5.1 \%)$ and video conferencing (5.1\%). The respondents were in the following business sectors: health or pharmaceutical (29.5\%), IT business services $(29.5 \%)$ and others (24.1\%); retail government (15.6\%), public services (13.5\%), education (6.8\%), manufacturing (5.1\%), and insurance (5.1\%). The size of employees in the BUMDes involved were less than 10 employees (84.4\%), 11-50 (13.5\%), and more than 51 employees (1.7\%). Most of the BUMDes were located in urban areas $(75.5 \%)$, while the remaining were in suburban $(17.7 \%)$ and rural areas $(6.8 \%)$. There were slightly more female $(60.8 \%)$ than male respondents (39.2\%) in this study. The kinds of technology the YCEs used were communication systems, such as groupware and e-mail (34.2\%), transactional systems for accounting finance, marketing, etc. (24.5\%), desktop suites, such as word processing, productivity (15.2\%), inter-organizational information systems, such as EDI, Electronic Business (15.6\%), decision support systems for accounting, finance, marketing, etc. (12.2\%), enterprise systems, such as ERP and CRM (3.4\%), and others (8.4\%). The positions of the respondents 
were owners $(20.7 \%)$, CEO (3.4\%), operation manager $(5.1 \%)$, line manager (11.8\%), and staff (59.1\%). In terms of age, nearly half of the respondents were less than 25 years old (47.7\%) and $26-40$ years old (43.9\%), while the remaining were more than 41 years old $(8.4 \%)$. Their educational backgrounds were high school (38\%), diploma (30.8\%), bachelor's degree (19.4\%), and master's degree (11.8\%). Among the respondents, $22.8 \%$ of them had professional qualifications in IT. The total business capital of the YCEs were in the following categories: less than IDR 15,000,000 (27.8\%), IDR 15,000,000-30,000,000 (17.3\%); IDR $30,000,000-60,000,000$ (11.8\%); IDR60,000,000-150,000,000 (12.2\%), and IDR150,000,000-300,000,000 (30.8\%).

Table 2: Demographic profile of respondents $(n=237)$

\begin{tabular}{lcc}
\hline \multicolumn{1}{c}{ Demographics } & Frequency & $\begin{array}{c}\text { Valid } \\
\text { Percent }\end{array}$ \\
\hline Company utilise the Internet product for: & & \\
1. Electronic mail & & \\
2. Document transferring & & \\
3. Financial: paying bills, salaries, & 56 & 23.6 \\
invoicing, etc. & 45 & 19 \\
4. Marketing & 83 & 35.0 \\
5. Submitting tenders to customers & 56 & 23.6 \\
6. Purchasing raw materials, office & 16 & 6.8 \\
supplies, etc. & 20 & 8.4 \\
7. Making order information available to & 57 & 24.1 \\
customers & 12 & 5.1 \\
8. Interaction with government & 12 & 5.1 \\
9. Voice/Audio communication (VOIP) & 12 & 5.1 \\
10. Video conferencing & & \\
\hline
\end{tabular}




\begin{tabular}{lcc}
\hline \multicolumn{1}{c}{ Demographics } & Frequency & $\begin{array}{c}\text { Valid } \\
\text { Percent }\end{array}$ \\
\hline Business sector & & \\
1. Education & 16 & 6.8 \\
2. Manufacturing & 12 & 5.1 \\
3. Retail Government & 37 & 15.6 \\
4. Public Services & 32 & 13.5 \\
5. Banking/Finance & - & - \\
6. Insurance & 12 & 5.1 \\
7. Construction & - & - \\
8. Health/Pharmaceutical & 25 & 10.5 \\
9. Business Services/IT business services & 70 & 29.5 \\
10. Other & 57 & 24.1 \\
\hline Number of Employees & & \\
1. Less than 10 & 201 & 84.8 \\
2. 11 - 50 & 32 & 13.5 \\
3. More than 51 & 4 & 1.7 \\
\hline Company location & & \\
1. Urban & 179 & 75.5 \\
2. Sub Urban & 42 & 17.7 \\
3. Rural & 16 & 6.8 \\
\hline Gender & & \\
1. Male & 93 & 39.2 \\
2. Female & 144 & 60.8 \\
\hline
\end{tabular}




\begin{tabular}{|c|c|c|}
\hline Demographics & Frequency & $\begin{array}{c}\text { Valid } \\
\text { Percent }\end{array}$ \\
\hline \multicolumn{3}{|l|}{ Level of applications } \\
\hline \multicolumn{3}{|l|}{$\begin{array}{l}\text { 1. Desktop suites (e.g. Word processing, } \\
\text { productivity) }\end{array}$} \\
\hline \multicolumn{3}{|l|}{$\begin{array}{l}\text { 2. Communication systems (e.g. } \\
\text { groupware, e-mail) }\end{array}$} \\
\hline \multirow{2}{*}{\multicolumn{3}{|c|}{$\begin{array}{l}\text { 3. Transactional systems for accounting } \\
\text { finance, marketing, etc. }\end{array}$}} \\
\hline & 36 & 15.2 \\
\hline \multirow{2}{*}{$\begin{array}{l}\text { 4. Decision support systems for } \\
\text { accounting, finance, marketing, etc. }\end{array}$} & 81 & 34.2 \\
\hline & 58 & 24.5 \\
\hline 5. Enterprise systems (ERP, CRM) & 29 & 12.2 \\
\hline \multirow{2}{*}{$\begin{array}{l}\text { 6. Inter-organisational Information } \\
\text { systems (EDI, Electronic Business) }\end{array}$} & 8 & 3.4 \\
\hline & 37 & 15.6 \\
\hline 7. Other & 20 & 8.4 \\
\hline \multicolumn{3}{|l|}{ Job Position } \\
\hline 1. Founder/Owner & 49 & 20.7 \\
\hline 2. $\mathrm{CEO}$ & 8 & 3.4 \\
\hline 3. Operation Manager & 12 & 5.1 \\
\hline 4. Line Manager & 28 & 11.8 \\
\hline 5. Staff & 140 & 59.1 \\
\hline \multicolumn{3}{|l|}{ Age } \\
\hline 1. Less than 25 years old & 113 & 47.7 \\
\hline 2. $26-30$ years old & 104 & 43.9 \\
\hline 3. More than 31 years old & 20 & 8.4 \\
\hline \multicolumn{3}{|l|}{ Education Background } \\
\hline 1. High School & 90 & 38.0 \\
\hline 2. Diploma & 73 & 30.8 \\
\hline 3. Bachelor's degree & 46 & 19.4 \\
\hline 4. Master's degree & 28 & 11.8 \\
\hline 5. Doctoral Degree & - & - \\
\hline \multicolumn{3}{|l|}{ Professional qualification in IT } \\
\hline 1. No & 183 & 77.2 \\
\hline 2. Yes & 54 & 22.8 \\
\hline
\end{tabular}




\begin{tabular}{ccc}
\hline \multicolumn{1}{c}{ Demographics } & Frequency & $\begin{array}{c}\text { Valid } \\
\text { Percent }\end{array}$ \\
\hline The amounts of business capital & & \\
1. $\leq$ IDR 15,000,000 & & \\
2. $>$ IDR 15,000,000-30,000,000 & 66 & 27.8 \\
3. $>$ IDR30,000,000-60,000,000 & 41 & 17.3 \\
4. >IDR60,000,000-150,000,000 & 28 & 11.8 \\
5. $>$ IDR150,000,000-300,000,000 & 29 & 12.2 \\
\hline
\end{tabular}

The hypothesized model shows the results that do not support the model fit $(p<.05)$. This is expected as the hypothesized model is usually strictly confirmatory. Thus, the modification index was used to fit the data to the generated model. For that purpose, some items were removed. The remaining numbers of items for each construct were as follows: Perceived Usefulness (4 items), Perceived Ease of Use (5 items), Perceived Credibility (5 items), Internet Intention (5 items), and Internet Adoption (6 items).

Table 3 shows that the composite reliability (CR) coefficient value of each variable was greater than 0.70 . Hence, all variables had acceptable reliability coefficients. Table 3 also shows that the AVE values of each variable were greater than 0.5. Convergent validity can be established when composite reliability is 0.7 or higher, and the AVE is 0.5 or higher (Kim et al., 2017). CR and AVE in this measurement exceeded the minimum level, indicating a good convergent validity.

Table 3: Convergent Validity

\begin{tabular}{lcc}
\hline \multicolumn{1}{c}{ Variables } & Composite reliability & AVE \\
\hline Perceived Usefulness & 0.973 & 0.955 \\
Perceived ease of use & 0.976 & 0.961 \\
Perceived Credibility & 0.860 & 0.649 \\
Internet Intention & 0.897 & 0.680 \\
Internet Adoption & 0.972 & 0.949 \\
\hline
\end{tabular}

Subsequently, a generated model (the same paths as the hypothesized model) was derived with a goodness of fit achieved ( $p>.05$ ). Thus, the generated 
model indicates better goodness of fit indices when some observed variables were deleted. Additionally, a re-specified model was derived whereby new paths have been suggested by modification indices and goodness of fit were achieved ( $p$.05). The hypotheses tested were based on the findings from the generated and re-specified model. Additionally, the analysis of the competing model or original model (TAM) was also conducted to examine the soundness of the root model, also showing p>.05 (Fig. 5).

Direct influences of the exogenous on the respective endogenous variables in the two structural models are shown in Table 4a-4c. Based on Standardized Beta estimates and critical ratio ( $\mathrm{CR}=\mathrm{t}$-values) values of $>1.96, \mathrm{H} 1$, $\mathrm{H} 3$, and H4 were supported in all generated and re-specified models. Therefore, it can be concluded that Perceived Usefulness is significantly and positively related to Intention; Perceived Credibility is significantly and positively related to intention; and Intention is significantly and positively related to Internet Adoption. Perceived Ease of Use is not significantly but positively related to Intention; thus, it was excluded. In the re-specified model, we also found three new paths, as suggested by modification indices results. These three new paths were assigned as $\mathrm{H} 1 \mathrm{a}, \mathrm{H} 2 \mathrm{a}$, and $\mathrm{H} 3 \mathrm{a}$, as in Table 5b. However, these three paths showed no significant impact on internet adoption. Thus, H1a, H2a, and H3a were rejected.

Table 4a: Direct Impact of Generated Model

\begin{tabular}{|c|c|c|c|c|c|c|}
\hline $\mathrm{H}$ & $\begin{array}{r}\text { Relatior } \\
\text { Exogenous }\end{array}$ & $\begin{array}{l}\text { nships between } \\
\text { and Endogenous }\end{array}$ & $\begin{array}{c}\text { Std. } \\
\text { Estimate }\end{array}$ & S.E. & C.R. & P-value \\
\hline H1 & $\begin{array}{l}\text { Internet } \\
\text { Intention }\end{array}$ & $\begin{array}{l}\text { Perceived } \\
\text { Usefulness }\end{array}$ & 0.340 & 0.103 & 2.943 & 0.003 \\
\hline $\mathrm{H} 2$ & $\begin{array}{l}\text { Internet } \\
\text { Intention }\end{array}$ & $\begin{array}{l}\text { Perceived } \\
\text { Ease of Use }\end{array}$ & 0.186 & 0.156 & 1.050 & 0.294 \\
\hline H3 & $\begin{array}{l}\text { Internet } \\
\text { Intention }\end{array}$ & $\begin{array}{l}\text { Perceived } \\
\text { Credibility }\end{array}$ & 0.425 & 0.220 & 2.078 & 0.038 \\
\hline $\mathrm{H} 4$ & $\begin{array}{l}\text { Internet } \\
\text { Adoption }\end{array}$ & $\begin{array}{l}\text { Internet } \\
\text { Intention }\end{array}$ & 0.923 & 0.191 & 7.176 & 0.000 \\
\hline
\end{tabular}


Table 4b: Direct Impact of Re-specified Model

\begin{tabular}{|c|c|c|c|c|c|c|}
\hline $\mathrm{H}$ & $\begin{array}{l}\text { Relationshis } \\
\text { Exogenous and }\end{array}$ & $\begin{array}{l}\text { s between } \\
\text { Endogenous }\end{array}$ & $\begin{array}{c}\text { Std. } \\
\text { Estimate }\end{array}$ & S.E. & C.R. & P-value \\
\hline $\mathrm{H} 1$ & $\begin{array}{l}\text { Internet } \\
\text { Intention }\end{array}$ & $\begin{array}{l}\text { Perceived } \\
\text { Usefulness }\end{array}$ & 0.316 & 0.103 & 2.943 & 0.032 \\
\hline $\mathrm{H} 2$ & $\begin{array}{l}\text { Internet } \\
\text { Intention }\end{array}$ & $\begin{array}{l}\text { Perceived } \\
\text { Ease of Use }\end{array}$ & 0.137 & 0.156 & 1.050 & 0.553 \\
\hline $\mathrm{H} 3$ & $\begin{array}{l}\text { Internet } \\
\text { Intention }\end{array}$ & $\begin{array}{l}\text { Perceived } \\
\text { Credibility }\end{array}$ & 0.392 & 0.220 & 2.078 & 0.120 \\
\hline $\mathrm{H} 4$ & $\begin{array}{l}\text { Internet } \\
\text { Adoption }\end{array}$ & $\begin{array}{l}\text { I } \mathrm{n} t \text { e } \mathrm{r} n \text { e } \mathrm{t} \\
\text { Intention }\end{array}$ & 0.432 & 0.191 & 7.176 & 0.001 \\
\hline $\begin{array}{l}\text { H1a } \\
\text { (new) }\end{array}$ & $\begin{array}{l}\text { Internet } \\
\text { Adoption }\end{array}$ & $\begin{array}{l}\text { Perceived } \\
\text { Usefulness }\end{array}$ & 0.178 & 0.144 & 1.630 & 0.103 \\
\hline $\begin{array}{l}\mathrm{H} 2 \mathrm{a} \\
\text { (new) }\end{array}$ & $\begin{array}{l}\text { Internet } \\
\text { Adoption }\end{array}$ & $\begin{array}{l}\text { Perceived } \\
\text { Ease of Use }\end{array}$ & 0.135 & 0.211 & 0.840 & 0.401 \\
\hline $\begin{array}{l}\text { H3a } \\
\text { (new) }\end{array}$ & $\begin{array}{l}\text { Internet } \\
\text { Adoption }\end{array}$ & $\begin{array}{l}\text { Perceived } \\
\text { Credibility }\end{array}$ & 0.218 & 0.300 & 1.170 & 0.242 \\
\hline
\end{tabular}

Table 4c: Direct Impact of Competing Model of TAM

\begin{tabular}{llcllll}
\hline Exogenous & Endogenous & $\begin{array}{c}\text { Std. } \\
\text { Estimate }\end{array}$ & S.E. & C.R. & P & Relationships \\
\hline Perceived & Internet & & & & & \\
Usefulness & Intention & 0.418 & 0.102 & 3.578 & 0.000 & Significant \\
Perceived & Internet & 0.495 & 0.104 & 4.104 & 0.000 & Significant \\
Ease of Use & Intention & 0.947 & 0.206 & 7.093 & 0.000 & Significant \\
Internet & Internet & & & & & \\
Intention & Adoption & & & & & \\
\hline
\end{tabular}

The indirect influences of exogenous variables on Internet Adoption through Intention are shown in Table 5a to 5c. In the generated model, two indirect estimates were significant but reduced compared to direct impacts (Table 5a-5c). Thus, $\mathrm{H} 5$ and $\mathrm{H} 7$ were supported. This means that Intention partially mediated the relationships between Perceived Usefulness and Perceived Credibility with Internet Adoption. Thus, $\mathrm{H} 5$ to $\mathrm{H} 7$ were supported, meaning that Intention is a partial mediator. In contrast, Intention did not mediate the relationship between Perceived Ease of Use and Internet Adoption. 
Structural equation modeling of internet of things (IoT) ... (Bustami Usman, Ilham Sentosa, Febri Nurrahmi)

Table 5a: Indirect Effect (Mediating Effect) of Internet Intention of the Generated Model

\begin{tabular}{|c|c|c|c|c|c|c|}
\hline $\mathrm{H}$ & Exogenous & Mediated & Endogenous & Path & $\begin{array}{l}\text { Indirect } \\
\text { Effect } \\
\text { Estimate }\end{array}$ & $\begin{array}{l}\text { Mediating } \\
\text { Hypothesis }\end{array}$ \\
\hline H5 & $\begin{array}{l}\text { Perceived } \\
\text { Usefulness }\end{array}$ & $\begin{array}{c}\text { Internet } \\
\text { Intention }\end{array}$ & $\begin{array}{c}\text { Internet } \\
\text { Adoption }\end{array}$ & $\begin{array}{c}\mathrm{PU} \rightarrow \text { Intention } \\
\rightarrow \text { Adoption } \\
(0.340 * 0.923)\end{array}$ & 0.314 & $\begin{array}{c}\text { Partial } \\
\text { Mediating }\end{array}$ \\
\hline H6 & $\begin{array}{l}\text { Perceived } \\
\text { Ease of } \\
\text { Use }\end{array}$ & $\begin{array}{l}\text { Internet } \\
\text { Intention }\end{array}$ & $\begin{array}{l}\text { Internet } \\
\text { Adoption }\end{array}$ & $\begin{array}{c}\text { EOU } \rightarrow \text { Intention } \\
\rightarrow \text { Adoption } \\
(0.186 * 0.923)\end{array}$ & 0.171 & $\begin{array}{c}\text { Not } \\
\text { Mediating }\end{array}$ \\
\hline $\mathrm{H} 7$ & $\begin{array}{l}\text { Perceived } \\
\text { Credibility }\end{array}$ & $\begin{array}{l}\text { Internet } \\
\text { Intention }\end{array}$ & $\begin{array}{l}\text { Internet } \\
\text { Adoption }\end{array}$ & $\begin{array}{c}\text { CRE } \rightarrow \text { Intention } \\
\rightarrow \text { Adoption } \\
(0.425 * 0.923)\end{array}$ & 0.392 & $\begin{array}{c}\text { Partial } \\
\text { Mediating }\end{array}$ \\
\hline
\end{tabular}

Conversely, Table $5 \mathrm{~b}$ showed no mediating effects of Intention on all hypothesized paths for the re-specified model. This is because the indirect effects were smaller than the direct effects (Table 4a-4c). Interestingly, in TAM competing model, intention only served as a partial mediator, not a full mediator, as suggested by Davis (1989).

Table 5b: Indirect Effect (Mediating Effect) of Internet Intention of the Respecified Model

\begin{tabular}{|c|c|c|c|c|c|c|}
\hline $\mathrm{H}$ & Exogenous & Mediated & Endogenous & Path & $\begin{array}{l}\text { Indirect } \\
\text { Effect } \\
\text { Estimate }\end{array}$ & $\begin{array}{l}\text { Mediating } \\
\text { Hypothesis }\end{array}$ \\
\hline $\mathrm{H} 5$ & $\begin{array}{l}\text { Perceived } \\
\text { Usefulness }\end{array}$ & $\begin{array}{l}\text { Internet } \\
\text { Intention }\end{array}$ & $\begin{array}{l}\text { Internet } \\
\text { Adoption }\end{array}$ & $\begin{array}{l}\mathrm{PU} \rightarrow \text { Intention } \rightarrow \\
\text { Adoption } \\
\left(0.316^{*} 0.432\right)\end{array}$ & 0.136 & $\begin{array}{c}\text { Not } \\
\text { Mediating }\end{array}$ \\
\hline H6 & $\begin{array}{l}\text { Perceived } \\
\text { Ease of Use }\end{array}$ & $\begin{array}{l}\text { Internet } \\
\text { Intention }\end{array}$ & $\begin{array}{l}\text { Internet } \\
\text { Adoption }\end{array}$ & $\begin{array}{l}\text { EOU } \rightarrow \text { Intention } \\
\rightarrow \text { Adoption } \\
(0.137 * 0.432)\end{array}$ & 0.059 & $\begin{array}{c}\text { Not } \\
\text { Mediating }\end{array}$ \\
\hline $\mathrm{H} 7$ & $\begin{array}{l}\text { Perceived } \\
\text { Credibility }\end{array}$ & $\begin{array}{l}\text { Internet } \\
\text { Intention }\end{array}$ & $\begin{array}{l}\text { Internet } \\
\text { Adoption }\end{array}$ & $\begin{array}{l}\text { CRE } \rightarrow \text { Intention } \\
\rightarrow \text { Adoption } \\
(0.392 * 0.432)\end{array}$ & 0.169 & $\begin{array}{c}\text { Not } \\
\text { Mediating }\end{array}$ \\
\hline
\end{tabular}


Informasi, Vol. 51. No. 1. (2021), 169-194

Table 5c: Indirect Effect (Mediating Effect) of Internet Intention of Competing Model

\begin{tabular}{|c|c|c|c|c|c|c|}
\hline $\mathrm{H}$ & Exogenous & Mediated & Endogenous & Path & $\begin{array}{l}\text { Indirect } \\
\text { Effect } \\
\text { Estimate }\end{array}$ & $\begin{array}{l}\text { Mediating } \\
\text { Hypothesis }\end{array}$ \\
\hline H5 & $\begin{array}{l}\text { Perceived } \\
\text { Usefulness }\end{array}$ & $\begin{array}{l}\text { Internet } \\
\text { Intention }\end{array}$ & $\begin{array}{l}\text { Internet } \\
\text { Adoption }\end{array}$ & $\begin{array}{l}\mathrm{PU} \rightarrow \text { Intention } \\
\rightarrow \text { Adoption } \\
\left(0.418^{*} 0.947\right)\end{array}$ & 0.395 & $\begin{array}{c}\text { Partial } \\
\text { Mediating }\end{array}$ \\
\hline H6 & $\begin{array}{l}\text { Perceived } \\
\text { Ease of Use }\end{array}$ & $\begin{array}{l}\text { Internet } \\
\text { Intention }\end{array}$ & $\begin{array}{l}\text { Internet } \\
\text { Adoption }\end{array}$ & $\begin{array}{l}\text { EOU } \rightarrow \text { Intention } \\
\rightarrow \text { Adoption } \\
(0.495 * 0.947)\end{array}$ & 0.468 & $\begin{array}{c}\text { Partial } \\
\text { Mediating }\end{array}$ \\
\hline
\end{tabular}

Table 6 illustrates the overall comparison between four structural models (hypothesized, generated, re-specified, and TAM competing models) derived from the study. It showed that the goodness of fit of the structural models (generated model, re-specified and competing models) achieved better goodness of fit compared to the hypothesized model. Among the three models, the respecified model achieved the highest absolute fit, indicating by its highest $\mathrm{p}$-value $(\mathrm{p}=0.144)$. In addition, it showed that the hypothesized and generated models both produced three significant direct impacts (Perceived Usefulness and Internet Intention; Perceived Credibility and Intention; and Internet Intention and Internet Adoption). The re-specified model yielded two significant direct impacts (Perceived Usefulness and Intention; Intention and Internet Adoption). It also indicates that Intention and Adoption consistently showed a significant positive effect in all structural models. Similarly, the TAM competing model supported all three direct and significant impacts, i.e., Perceived Usefulness to Intention, Perceived Ease of Use to Intention, and Intention to Adoption. Concerning the indirect or mediating effects, Intention partially mediated the path between Perceived Usefulness and Adoption in the three structural models (hypothesized, generated, and competing model). Intention acted as a partial mediator between Perceived Credibility and Adoption in the two structural models (hypothesized and generated model). However, Intention was not a mediator between Perceived Ease of Use and Adoption in all structural models, except a partial mediator in the TAM competing model. Table 6 also shows the nested model comparisons between the four structural models. All Chi-square and $\mathrm{df}$ change between models were more than 3.84 or $>1 \mathrm{df}$ respectively. Thus, the nested model tests could be substantiated (Hair, Black, Babin, \& Anderson, 
Structural equation modeling of internet of things (IoT) ... (Bustami Usman, Ilham Sentosa, Febri Nurrahmi)

2013; Sentosa, Bambang, Ming, \& Kamaria, 2012; Tabachnick et al., 2012).

Table 6: Comparison between Hypothesized, Generated, Re-specified, and Competing Model

\begin{tabular}{|c|c|c|c|c|c|c|c|c|c|c|c|c|c|c|c|}
\hline \multirow[b]{2}{*}{$\mathbf{H}$} & \multirow[b]{2}{*}{$\begin{array}{l}\text { Endoge } \\
\text { nous }\end{array}$} & \multirow[b]{2}{*}{$\begin{array}{l}\text { Media } \\
\text { tion }\end{array}$} & \multirow[b]{2}{*}{$\begin{array}{l}\text { Exoge } \\
\text { nous }\end{array}$} & \multicolumn{3}{|c|}{ Hypothesized Model } & \multicolumn{3}{|c|}{ Generated Model } & \multicolumn{3}{|c|}{ Re-Specified Model } & \multicolumn{3}{|c|}{$\begin{array}{c}\text { Competing Model } \\
\text { of TAM }\end{array}$} \\
\hline & & & & $\begin{array}{l}\text { Std. } \\
\text { Estim } \\
\text { ate }\end{array}$ & $\mathbf{P}$ & $\begin{array}{c}\text { Hypot } \\
\text { hesis } \\
\text { Status }\end{array}$ & $\begin{array}{l}\text { Std. } \\
\text { Estim } \\
\text { ate }\end{array}$ & $\mathbf{P}$ & $\begin{array}{l}\text { Hypot } \\
\text { hesis } \\
\text { Status }\end{array}$ & $\begin{array}{l}\text { Std. } \\
\text { Estim } \\
\text { ate }\end{array}$ & $\mathbf{p}$ & $\begin{array}{l}\text { Hypot } \\
\text { hesis } \\
\text { Status }\end{array}$ & $\begin{array}{l}\text { Std. } \\
\text { Estim } \\
\text { ate }\end{array}$ & $\mathbf{p}$ & $\begin{array}{c}\text { Hypoth } \\
\text { esis } \\
\text { Status }\end{array}$ \\
\hline $\begin{array}{l}\mathrm{H} \\
1\end{array}$ & $\begin{array}{l}\text { Perceiv } \\
\text { ed } \\
\text { Usefuln } \\
\text { ess }\end{array}$ & - & $\begin{array}{l}\text { Intern } \\
\text { et } \\
\text { Intenti } \\
\text { on }\end{array}$ & 0.305 & Sig & $\begin{array}{l}\text { Suppor } \\
\text { ted }\end{array}$ & 0.340 & Sig & $\begin{array}{l}\text { Suppor } \\
\text { ted }\end{array}$ & 0.316 & Sig & $\begin{array}{l}\text { Suppor } \\
\text { ted }\end{array}$ & 0.418 & $\begin{array}{l}\mathrm{Si} \\
\mathrm{g}\end{array}$ & $\begin{array}{l}\text { Suppor } \\
\text { ted }\end{array}$ \\
\hline $\begin{array}{l}\mathrm{H} \\
2\end{array}$ & $\begin{array}{l}\text { Perceiv } \\
\text { ed Ease } \\
\text { of Use }\end{array}$ & - & $\begin{array}{l}\text { Intern } \\
\text { et } \\
\text { Intenti } \\
\text { on }\end{array}$ & 0.203 & $\begin{array}{l}\text { No } \\
\mathrm{t} \\
\mathrm{sig} \\
\mathrm{r}\end{array}$ & $\begin{array}{c}\text { Reject } \\
\text { ed }\end{array}$ & 0.186 & $\begin{array}{l}\text { No } \\
t \\
\text { sig }\end{array}$ & $\begin{array}{c}\text { Rejecte } \\
\text { d }\end{array}$ & 0.137 & $\begin{array}{c}\text { No } \\
t \\
\text { sig } \\
\text {. }\end{array}$ & $\begin{array}{l}\text { Rejecte } \\
\quad \mathrm{d}\end{array}$ & 0.495 & $\begin{array}{l}\mathrm{Si} \\
\mathrm{g}\end{array}$ & $\begin{array}{l}\text { Suppor } \\
\text { ted }\end{array}$ \\
\hline $\begin{array}{l}\mathrm{H} \\
3\end{array}$ & $\begin{array}{l}\text { Perceiv } \\
\text { ed } \\
\text { Credibil } \\
\text { ity }\end{array}$ & - & $\begin{array}{l}\text { Intern } \\
\text { et } \\
\text { Intenti } \\
\text { on }\end{array}$ & 0.437 & Sig & $\begin{array}{l}\text { Suppor } \\
\text { ted }\end{array}$ & 0.425 & Sig & $\begin{array}{l}\text { Suppor } \\
\text { ted }\end{array}$ & 0.392 & $\begin{array}{c}\text { No } \\
t \\
\text { sig } \\
\text {. }\end{array}$ & $\begin{array}{c}\text { Rejecte } \\
\mathrm{d}\end{array}$ & - & - & - \\
\hline $\begin{array}{l}\mathrm{H} \\
4\end{array}$ & $\begin{array}{l}\text { Interne } \\
\mathrm{t} \\
\text { Intentio } \\
\mathrm{n}\end{array}$ & - & $\begin{array}{l}\text { Intern } \\
\text { et } \\
\text { Adopti } \\
\text { on }\end{array}$ & 0.927 & Sig & $\begin{array}{l}\text { Suppor } \\
\text { ted }\end{array}$ & 0.923 & Sig & $\begin{array}{l}\text { Suppor } \\
\text { ted }\end{array}$ & 0.432 & Sig & $\begin{array}{l}\text { Suppor } \\
\text { ted }\end{array}$ & 0.947 & $\begin{array}{l}\mathrm{Si} \\
\mathrm{g}\end{array}$ & $\begin{array}{l}\text { Suppor } \\
\text { ted }\end{array}$ \\
\hline $\begin{array}{l}\mathrm{H} \\
5\end{array}$ & $\begin{array}{l}\text { Perceiv } \\
\text { ed } \\
\text { Usefuln } \\
\text { ess }\end{array}$ & $\begin{array}{l}\text { Intern } \\
\text { et } \\
\text { Intenti } \\
\text { on }\end{array}$ & $\begin{array}{l}\text { Intern } \\
\text { et } \\
\text { Adopti } \\
\text { on }\end{array}$ & 0.282 & Sig & $\begin{array}{l}\text { Suppor } \\
\text { ted }\end{array}$ & 0.314 & Sig & $\begin{array}{c}\text { Suppor } \\
\text { ted } \\
\text { (Partial } \\
\text { ) }\end{array}$ & 0.136 & $\begin{array}{c}\text { No } \\
t \\
\text { sig } \\
\text {. }\end{array}$ & $\begin{array}{c}\text { Rejecte } \\
\text { d } \\
\text { (Not } \\
\text { Mediat } \\
\text { ing) }\end{array}$ & 0.395 & $\begin{array}{l}\mathrm{Si} \\
\mathrm{g}\end{array}$ & $\begin{array}{l}\text { Suppor } \\
\text { ted } \\
\text { (Partial } \\
\text { ) }\end{array}$ \\
\hline $\begin{array}{l}H \\
6\end{array}$ & $\begin{array}{l}\text { Perceiv } \\
\text { ed Ease } \\
\text { of Use }\end{array}$ & $\begin{array}{l}\text { Intern } \\
\text { et } \\
\text { Intenti } \\
\text { on }\end{array}$ & $\begin{array}{l}\text { Intern } \\
\text { et } \\
\text { Adopti } \\
\text { on }\end{array}$ & 0.188 & $\begin{array}{l}\text { No } \\
\mathrm{t} \\
\mathrm{sig} \\
\cdot\end{array}$ & $\begin{array}{c}\text { Reject } \\
\text { ed }\end{array}$ & 0.171 & $\begin{array}{l}\text { No } \\
t \\
\text { sig }\end{array}$ & $\begin{array}{c}\text { Rejecte } \\
\text { d } \\
\text { (Not } \\
\text { Mediat } \\
\text { ing) }\end{array}$ & 0.059 & $\begin{array}{c}\text { No } \\
\text { t } \\
\text { sig } \\
\text {. }\end{array}$ & $\begin{array}{c}\text { Rejecte } \\
\text { d } \\
\text { (Not } \\
\text { Mediat } \\
\text { ing) }\end{array}$ & 0.468 & $\begin{array}{l}\mathrm{Si} \\
\mathrm{g}\end{array}$ & $\begin{array}{l}\text { Suppor } \\
\text { ted } \\
\text { (Partial } \\
\text { ) }\end{array}$ \\
\hline $\begin{array}{l}\mathrm{H} \\
7\end{array}$ & $\begin{array}{l}\text { Perceiv } \\
\text { ed } \\
\text { Credibil } \\
\text { ity }\end{array}$ & $\begin{array}{l}\text { Intern } \\
\text { et } \\
\text { Intenti } \\
\text { on }\end{array}$ & $\begin{array}{l}\text { Intern } \\
\text { et } \\
\text { Adopti } \\
\text { on }\end{array}$ & 0.405 & Sig & $\begin{array}{l}\text { Suppor } \\
\text { ted }\end{array}$ & 0.392 & Sig & $\begin{array}{c}\text { Suppor } \\
\text { ted } \\
\text { (Partial } \\
\text { ) }\end{array}$ & 0.169 & $\begin{array}{c}\text { No } \\
\text { t } \\
\text { sig } \\
\text {. }\end{array}$ & $\begin{array}{c}\text { Rejecte } \\
\text { d } \\
\text { (Not } \\
\text { Mediat } \\
\text { ing) }\end{array}$ & - & - & - \\
\hline \multicolumn{16}{|c|}{ The Goodness of Fit Index: } \\
\hline & -Square & & & \multicolumn{3}{|c|}{540.394} & \multicolumn{3}{|l|}{299.122} & \multicolumn{3}{|l|}{289.512} & \multicolumn{3}{|c|}{141.000} \\
\hline \multicolumn{4}{|c|}{ Chi-square $\Delta$} & & & & \multicolumn{3}{|l|}{241.272} & \multicolumn{3}{|l|}{9.61} & \multicolumn{3}{|c|}{148.512} \\
\hline \multicolumn{4}{|c|}{$\mathrm{df}$} & \multicolumn{3}{|l|}{427} & \multicolumn{3}{|l|}{268} & \multicolumn{3}{|l|}{265} & \multicolumn{3}{|l|}{115} \\
\hline \multicolumn{4}{|c|}{ df $\Delta$} & & & & \multicolumn{3}{|l|}{159} & \multicolumn{3}{|l|}{3} & \multicolumn{3}{|l|}{150} \\
\hline \multicolumn{4}{|c|}{ Ratio } & \multicolumn{3}{|l|}{1.266} & \multicolumn{3}{|l|}{1.116} & \multicolumn{3}{|l|}{1.092} & \multicolumn{3}{|l|}{1.226} \\
\hline & 'alue & & & 0.000 & & & 0.093 & & & 0.144 & & & 0.050 & & \\
\hline GF & & & & 0.874 & & & 0.910 & & & 0.913 & & & 0.937 & & \\
\hline & ISEA & & & 0.034 & & & 0.022 & & & 0.020 & & & 0.987 & & \\
\hline $\mathrm{R}^{2}$ : & & & & & & & & & & & & & & & \\
\hline & ention & & & $77.5 \%$ & & & $78.9 \%$ & & & $62.4 \%$ & & & $75.1 \%$ & & \\
\hline $\mathrm{Ad}$ & option & & & $85.9 \%$ & & & $85.2 \%$ & & & $77.2 \%$ & & & $89.8 \%$ & & \\
\hline
\end{tabular}

This study attempts to examine the empirical relationships between technology usage perception and credibility with IoT adoption among BUMDes administrators. Additionally, this study also investigates the mediating effect of Intention to Use on those relationships as hypothesized based on the conceptual 
underpinning of TAM. The finding indicates that Perceived Usefulness is significantly and positively related to Internet Intention. This finding is in line with previous studies in the information systems community and provided evidence of the significant effect of Perceived Usefulness on Intention to use new technology (Hamid et al., 2016; Jaafreh, 2018; Kucukusta et al., 2015; Venkatesh \& Davis, 2000). This implies that YECs working in BUMDes have the intention to use IoT for increasing their productivity, enhancing effectiveness, and improving the BUMDES performance.

The present study found Perceived Ease of Use is insignificantly but positively related to Intention. Polatoglu and Ekin (2001) reported a similar result in their study. They argue that ease of use may not be utilized if it is not perceived as useful; thus, we conclude that the YCE's perceived usefulness of IoT is the key construct for adoption among entrepreneurs. Contrastingly, numerous studies had found a positive and significant relationship between the two variables (Hamid et al., 2016; Kucukusta et al., 2015; Moon \& Kim, 2001; Venkatesh \& Davis, 2000). The possible explanation for this difference could be that most managers and staff of BUMDes still find internet technology challenging to understand. Hence, they need to undergo more trainings to improve this situation.

Perceived credibility is also found to be significantly and positively related to intention. This finding is supported by previous studies (Goyal et al., 2013; Koksal, 2016). Those YCE owners who feel that the Internet has high security, privacy, and trustworthiness of information would definitely have a high intention of using IoT.

Lastly, intention is found to be significantly and positively related to internet adoption. A previous study has found similar findings (Jaafreh, 2018; Karahoca et al., 2018). The direct path from Intention to Adoption is the most consistent finding across all models; thus, it can be deduced that those in BUMDes who have the intention to use the IoT would definitely adopt IoT in the future.

This study also found partial mediating effects of Intention on the relationships between Perceived Usefulness, Perceived Credibility, and Perceived Ease of Use with IoT Adoption. The additional findings on the new paths in the re-specified model support mediating effects for these relationships. Our findings found substantial partial mediating effects. This could imply that the adoption of the Internet may not be a direct process. Often, intention is profoundly necessary to enhance the relationship concerned. 


\section{CONCLUSION}

This research investigates the predictors and mediating effects of intention on internet adoption YCEs in BUMDes using TAM conceptual underpinning theory. The findings supported the TAM theory, whereby all the hypothesized paths were supported. The generated model found three significant direct paths between Perceived Usefulness, Perceived Credibility, and Intention as well as between intention and adoption. The re-specified model produces two significant direct paths (Perceived Usefulness to Intention and Intention to Adoption) and introduces three new paths (direct paths from Perceived Usefulness, Perceived Ease of Use, and Perceived Credibility Adoption). The model also manages to establish partial mediating effects of Intention on the relationships between exogenous variables and internet adoption. Future research should investigate other underpinning TAM theory, such as TAM2 (Venkatesh \& Davis, 2000) and extended TAM (Hsu Meng, Chiu Chao, \& Ju Teresa, 2004). The importance of BUMDes cannot be denied, but unfortunately it is still very much underresearched.

\section{REFERENCES}

Abd Rahman, A., Kamarulzaman, N. H., \& Sambasivan, M. (2013). A study on organizational culture, performance, and technological adoption behaviours of Malaysian food-processing SMEs. Pertanika Journal of Social Sciences $\mathcal{E}$ Humanities, 21, 231-256. Retrieved from http://psasir.upm. edu.my/id/eprint/28340/

Abdullah, F., Ward, R., \& Ahmed, E. (2016). Investigating the influence of the most commonly used external variables of TAM on students' Perceived Ease of Use (PEOU) and Perceived Usefulness (PU) of e-portfolios. Computers in Human Behavior, 63, 75-90. doi:https://doi.org/10.1016/j. chb.2016.05.014

Al-Jader, R. A., \& Sentosa, I. (2015). A Conceptual Development on the Mediating Role of E-Service Recovery on The Relationship between Customer Determinants and Customer Retentions in The Airline Industry in Malaysia (A Structural Equation Modelling Approach). Indian Journal of Commerce and Management Studies, 6(1), 103. Retrieved from http://jurnal.unsyiah.ac.id/AICS-Social/article/view/10348 
Azjen, I. (1980). Understanding attitudes and predicting social behavior. Englewood Cliffs, NJ: Prentice-Hall.

Bagozzi, R. P., \& Yi, Y. (1988). On the evaluation of structural equation models. Journal of the academy of marketing science, 16(1), 74-94. https://doi. org/10.1007/BF02723327

Davis, F. D. (1989). Perceived usefulness, perceived ease of use, and user acceptance of information technology. MIS quarterly, 319-340. DOI: $10.2307 / 249008$

Davis, F. D., Bagozzi, R. P., \& Warshaw, P. R. (1989). User acceptance of computer technology: a comparison of two theoretical models. Management science, 35(8), 982-1003. DOI:10.1287/mnsc.35.8.982

Florida, R. (2002). The rise of the creative class (Vol. 9): Basic books New York.

Ganesan, S. (1994). Determinants of long-term orientation in buyerseller relationships. Journal of marketing, 58(2), 1-19. https://doi. org/10.2307/1252265

Goyal, A., Maity, M., Thakur, R., \& Srivastava, M. (2013). Customer usage intention of mobile commerce in India: an empirical study. Journal of Indian Business Research. 5 (1), 52-72. https://doi. org/10.1108/17554191311303385

Hadi, A. (2018). Bridging Indonesia's Digital Divide: Rural-Urban Linkages? Jurnal Ilmu Sosial dan Ilmu Politik, 22, 17. doi:10.22146/jsp.31835

Hair, J. F., Black, W. C., Babin, B. J., \& Anderson, R. E. (2013). Multivariate data analysis (7 ed.). Pearson Education Limited.

Hamid, A. A., Razak, F. Z. A., Bakar, A. A., \& Abdullah, W. S. W. (2016). The Effects of Perceived Usefulness and Perceived Ease of Use on Continuance Intention to Use E-Government. Procedia Economics and Finance, 35, 644649. doi:https://doi.org/10.1016/S2212-5671(16)00079-4

Hoffman, D. L., Novak, T. P., \& Peralta, M. (1999). Building consumer trust online. Communications of the ACM, 42(4), 80-85. DOI: $10.1145 / 299157.299175$

Hsu Meng, H., Chiu Chao, M., \& Ju Teresa, L. (2004). Determinants of continued use of the WWW: an integration of two theoretical models. Industrial Management Eु Data Systems, 104(9), 766-775. doi: $10.1108 / 02635570410567757$

Ibrahim, A. M. (2018). Strategizing small and medium enterprises development 
through ICT-related innovations adoption: moderating influence of gender, age and experience. Informasi, 48(1), 15-32. https://doi. org/10.21831/informasi.v48i1.18417

Jaafreh, A. B. (2018). The effect factors in the adoption of Internet of Things (IoT) technology in the SME in KSA: An empirical study. International Review of Management and Business Research, 7(1), 135-148. DOI:10.30543/71(2018)-13

Karahoca, A., Karahoca, D., \& Aksöz, M. (2018). Examining intention to adopt to internet of things in healthcare technology products. Kybernetes, 47(4), 742-770. doi:10.1108/K-02-2017-0045

Kim, Y., Park, Y., \& Choi, J. (2017). A study on the adoption of IoT smart home service: using Value-based Adoption Model. Total Quality Management $\mathcal{E}$ Business Excellence, 28(9-10), 1149-1165. https://doi.org/10.1080/147833 63.2017.1310708

Koksal, M. H. (2016). The intentions of Lebanese consumers to adopt mobile banking. International Journal of bank marketing. 34 (3), 327-346. https:// doi.org/10.1108/IJBM-03-2015-0025

Kucukusta, D., Law, R., Besbes, A., \& Legohérel, P. (2015). Re-examining perceived usefulness and ease of use in online booking. International Journal of Contemporary Hospitality Management. 27 (2), 185-198. https:// doi.org/10.1108/IJCHM-09-2013-0413

Lubis, A., Rustam, \& Muda, I. (2017). Factors affecting the cost of agency of village owned enterprise (BUMDEs) in Indonesia. International Journal of Economic Research, 14, 151-166.

Maranguniป, N., \& Granil, A. (2015). Technology acceptance model: a literature review from 1986 to 2013. Universal Access in the Information Society, 14(1), 81-95. doi:10.1007/s10209-014-0348-1

Moon, J.-W., \& Kim, Y.-G. (2001). Extending the TAM for a World-WideWeb context. Information $\mathcal{E}$ management, 38(4), 217-230. https://doi. org/10.1016/S0378-7206(00)00061-6

Nurchim, N., \& Nofikasari, I. (2018). Pemodelan adopsi teknologi digital guna mewujudkan desa pintar. Retrieved from https://publikasiilmiah.ums. ac.id/handle/11617/9871

Polatoglu, V. N., \& Ekin, S. (2001). An empirical investigation of the Turkish consumers' acceptance of Internet banking services. 
International Journal of bank marketing. 19 (4), 156-165. https://doi. org/10.1108/02652320110392527

Popescu, G. H. (2015). The economic value of the industrial internet of things. Journal of Self-Governance and Management Economics, 3(2), 86-91. Retrieved from https://www.addletonacademicpublishers.com/contents-jsme/313. volume-3-2-2015/2475-the-economic-value-of-the-industrial-internet-ofthings

Rayes, A., \& Salam, S. (2019). Internet of Things (IoT) Overview. In Internet of Things From Hype to Reality: The Road to Digitization (pp. 1-35). Springer International Publishing.

Rengiah, P., \& Sentosa, I. (2015). Entrepreneurship education and entrepreneurial intentions among Malaysian university students: Developing a hypothesised model through Structural Equation Modelling. Australian Journal of Basic and Applied Sciences, 9(7), 703-710. Retrieved from http://www.ajbasweb.com/old/ajbas/2015/April/703-710.pdf

Saade, R., Nebebe, F., \& Tan, W. (2007). Viability of the" technology acceptance model" in multimedia learning environments: a comparative study. Interdisciplinary Journal of E-Learning and Learning Objects, 3(1), 175-184. Retrieved from https://www.learntechlib.org/p/44804/.

Sentosa, I., Bambang, B. S., Ming, C. W. M. C. W., \& Kamaria, N. K. N. M. (2012). A structural equation modeling of internet banking usage in Malaysia. Journal of Art Science $\mathcal{E}$ Commerce, 3(1), 75-86. Retrieved from https://repository.unsri.ac.id/14568/

Srirejeki, K. (2018). Empowering the role of village owned enterprise (BUMDes) for rural development: Case in Indonesia. Jurnal Akuntansi, Manajemen dan Ekonomi, 20 (1). 5-10. Retrieved from http://jos.unsoed.ac.id/index. $\mathrm{php} /$ jame/article/view/1018

Statista. (2020). Countries with the highest number of internet users 2019. Retrieved from https://www.statista.com/statistics/262966/number-ofinternet-users-in-selected-countries/

Tabachnick, B. G., Fidell, L. S., \& Ullman, J. B. (2012). Using multivariate statistics (6 ed.). Pearson.

Venkatesh, V., \& Davis, F. D. (2000). A theoretical extension of the technology acceptance model: Four longitudinal field studies. Management science, 46(2), 186-204. https://doi.org/10.1287/mnsc.46.2.186.11926 
Structural equation modeling of internet of things (IoT) ... (Bustami Usman, llham Sentosa, Febri Nurrahmi)

Wang, Y. S., Wang, Y. M., Lin, H. H., \& Tang, T. I. (2003). Determinants of user acceptance of Internet banking: an empirical study. International journal of service industry management. 14 (5), 501-519. https://doi. org/10.1108/09564230310500192

Yan, R. (2017). Optimization approach for increasing revenue of perishable product supply chain with the Internet of Things. Industrial Management $\mathcal{E}$ Data Systems, 117(4), 729-741. doi:10.1108/IMDS-07-2016-0297

Zaidi, M. F. A., \& Faizal, M. (2017). The IoT readiness of SMEs in Malaysia: are they worthwhile for investigation. Paper presented at the International Conference on International Business, Marketing and Humanities 2017 (ICIBMAH 2017). Retrieved from http://repo.uum.edu.my/22935/

Zulpahmi, Z., Badaruddin, B., \& Humaizi, H. (2020). Peran modal sosial dalam pengelolaan Badan Usaha Milik Desa Maju Bersama di Desa Sei JawiJawi Kecamatan Sei Kepayang Barat Kabupaten Asahan. PERSPEKTIF, 9, 168-182. doi:10.31289/perspektif.v9i2.3346 
Informasi, Vol. 51. No. 1. (2021), 169-194 